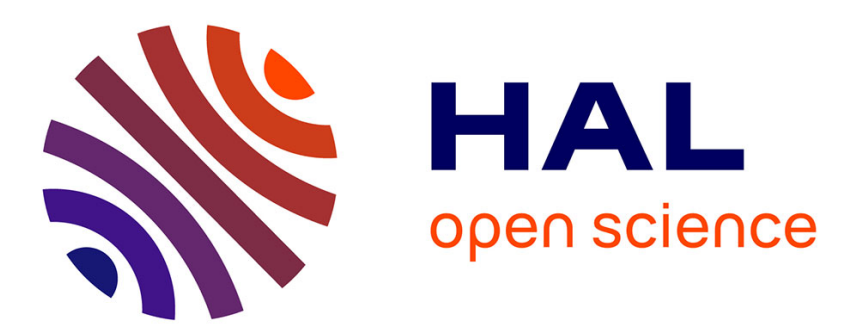

\title{
TGF-beta-induced SMAD signaling and gene regulation: consequences for extracellular matrix remodeling and wound healing.
}

\author{
Meinhard Schiller, Delphine Javelaud, Alain Mauviel
}

\section{- To cite this version:}

Meinhard Schiller, Delphine Javelaud, Alain Mauviel. TGF-beta-induced SMAD signaling and gene regulation: consequences for extracellular matrix remodeling and wound healing.. Journal of Dermatological Science, 2004, 35 (2), pp.83-92. 10.1016/j.jdermsci.2003.12.006 . inserm-00147401

\section{HAL Id: inserm-00147401 https://www.hal.inserm.fr/inserm-00147401}

Submitted on 21 May 2007

HAL is a multi-disciplinary open access archive for the deposit and dissemination of scientific research documents, whether they are published or not. The documents may come from teaching and research institutions in France or abroad, or from public or private research centers.
L'archive ouverte pluridisciplinaire HAL, est destinée au dépôt et à la diffusion de documents scientifiques de niveau recherche, publiés ou non, émanant des établissements d'enseignement et de recherche français ou étrangers, des laboratoires publics ou privés. 
TGF- $\beta$-induced SMAD signaling and gene regulation: consequences for extracellular matrix remodeling and wound healing

Meinhard Schiller, Delphine Javelaud, and Alain Mauvielף

INSERM U532, Institut de Recherche sur la Peau, Université Paris VII, Hôpital SaintLouis, Paris, France

KEYWORDS: Collagen Gene Expression; Fibrosis; Jun N-terminal Kinase;

Transforming Growth Factor- $\beta$; Wound Healing

ๆCorresponding author: A Mauviel, INSERM U532,

Institut de Recherche sur la Peau,

Pavillon Bazin, Hôpital Saint-Louis,

1, avenue Claude Vellefaux,

75010 Paris, France

Tel.: 33-1-53-72-20-69

Fax: 33-1-53-72-20-51

E-mail: mauviel@chu-stlouis.fr 
Summary Members of the transforming growth factor- $\beta$ (TGF- $\beta$ ) superfamily are pleiotropic cytokines that have the ability to regulate numerous cell functions, including proliferation, differentiation, apoptosis, epithelial-mesenchymal transition, and production of extracellular matrix, allowing them to play an important role during embryonic development and for maintenance of tissue homeostasis. Three TGF- $\beta$ isoforms have been identified in mammals. They propagate their signal via a signal transduction network involving receptor serine/threonine kinases at the cell surface and their substrates, the SMAD proteins. Upon phosphorylation and oligomerization, the latter move into the nucleus to regulate transcription of target genes. This review will summarize recent advances in the understanding of the mechanisms underlying SMAD modulation of extracellular matrix gene expression in the context of wound healing and tissue fibrosis. 


\section{Abbreviations}

$\begin{array}{ll}\text { BMP } & \text { bone morphogenic proteins } \\ \text { CBP } & \text { CREB Binding Protein } \\ \text { ECM } & \text { extracellular matrix } \\ \text { FKBP12 } & \text { FK506-binding protein } \\ \text { IFN- } \gamma & \text { interferon- } \gamma \\ \text { JNK } & \text { Jun-N-terminal kinase } \\ \text { MH } & \text { MAD Homology domain } \\ \text { NF- } k B & \text { nuclear factor } \kappa B \\ \text { NEMO } & \text { NF- } \kappa B \text { Essential Modulator } \\ \text { PAI-1 } & \text { plasminogen activator inhibitor-1 } \\ \text { SARA } & \text { SMAD anchor for receptor activation } \\ \text { SKI } & \text { Sloan-Kettering Institute proto-oncogene } \\ \text { SMAD } & \text { for SMA/MAD related } \\ \text { SnoN } & \text { Ski-related novel gene N } \\ \text { T } \beta \text { RI/II } & \text { TGF- } \beta \text { type I/II receptor protein } \\ \text { TGF- } \beta & \text { transforming growth factor- } \beta \\ \text { TGIF } & \text { TG3-interacting factor } \\ \text { TNF- } \alpha & \text { tumor necrosis factor- } \alpha\end{array}$




\section{The TGF- $\beta$ super-family}

The transforming growth factor- $\beta$ (TGF- $\beta$ ) superfamily, a large group of pleiotropic cytokines, consists of more than 30 structurally related factors found in vertebrates, insects, and nematodes. Phylogenically, members of the TGF- $\beta$ family are classified into several subfamilies including the bone morphogenic proteins (BMP), the activins, various intermediate members, and the TGF- $\beta$ subfamily (for review see $[1 ; 2]$ ). With their specific receptors being ubiquitously expressed, they are implicated in various cell functions, including apoptosis, proliferation, differentiation, motility, and adhesion. Accordingly, these factors play a pivotal role in physiological circumstances, including embryonic development and wound healing, and in pathological conditions such as cancer and tissue fibrosis.

Three structurally almost identical isoforms of TGF- $\beta$ (TGF- $\beta 1-3$ ), encoded by three distinct genes, have been identified in mammals. Their isoforms share a common structural knot motif consisting of six cysteine residues joined together by three intrachain disulfide bonds that stabilize the $\beta$-sheet bands. One free cysteine forms an interchain disulfide bond with an identical monomeric chain to permit formation of mature TGF- $\beta$ dimers and their secretion as large latent complex, covalently bound with latent TGF- $\beta$ binding protein. Activation of the LTGF- $\beta$ by cleavage of the latency associated peptide region by various proteases such as plasmin, thrombin or plasma transglutaminase, allows the bioactive TGF- $\beta$ to interact with specific receptors at the cell surface [3].

Even if their in vitro effects seem to be indistinguishable, knockout experiments in mice have revealed that each TGF- $\beta$ isoform plays an independent and non-redundant role during the course of embryonic development. For instance, targeted disruption of the mouse TGF- $\beta 1$ gene results to a wasting syndrome accompanied by a multifocal, 
mixed inflammatory cell reaction and tissue necrosis, leading ultimately to organ failure and death, indicating a critical role of TGF- $\beta 1$ in immune responses [4]. TGF- $\beta 2$ knockout mice have multiple severe developmental defects including cardiac, lung, craniofacial, limb, spinal column, eye, inner ear and urogenital defects [5]. Finally, mice lacking TGF- $\beta 3$ exhibit an incompletely penetrant phenotype characterized by failure of the palatal shelves to fuse, resulting in cleft palate. This defect results from impaired adhesion of the apposing medial edge epithelia of the palatal shelves and subsequent elimination of the mid-line epithelial seam, suggesting that TGF- $\beta 3$ is crucial for epithelial differentiation [6]. Of note, exogenous addition of TGF- $\beta 3$ to cutaneous experimental wounds reduces scarring in adult rats and leads to a final result that is almost indistinguishable from that of embryonic scarless wound healing $[7 ; 8]$. Together, their phenotypes emphasize the numerous non-compensatory functions of these three TGF- $\beta$ isoforms.

\section{TGF- $\beta$ receptors}

The TGF- $\beta$ superfamily members transduce their signal from the membrane to the nucleus through distinct combinations of transmembrane type I and type II serine/threonine receptors and their downstream effectors, known as SMAD proteins (Fig. 1) [2; 9]. So far, only one TGF- $\beta$ type II receptor protein (T $\beta R I I)$ has been isolated that binds TGF- $\beta$ s [10].

From the structural point of view, TGF- $\beta$ type I (TRRI) and II receptors are very similar glycoproteins, characterized by a cysteine-rich extracellular domain, a single hydrophobic transmembrane domain, and a C-terminal cytoplasmic serine/threonine kinase domain. The T $\beta$ Rls have a highly conserved regulatory segment rich in glycine and serine residues, known as the GS region, upstream of the serine/threonine kinase 
domain in the cytoplasmic portion of the receptor $[1 ; 11]$. Upon binding of its ligands, $T \beta R$ II recruits the $T \beta R$ I into an activated heterotetrameric receptor complex. T $\beta R$ II via its intrinsic kinase activity phosphorylates the $T \beta R$ I regulatory GS region. In turn the cytoplasmic $T \beta R I$ serine/threonine kinase domain is activated, leading to subsequent phosphorylation of its intracellular downstream effectors, SMAD proteins $[1 ; 9 ; 12]$. The nine amino acid sequence between kinase subdomains IV and $V$ in $T \beta R I$ s, termed the L45 loop, is a critical determinant in specifying activation of different SMAD proteins, thereby guaranteeing specificity in transcriptional responses [12]. Unphosphorylated T $\beta$ RI forms complexes with the FK506-binding protein (FKBP12). Binding of the latter to the GS region of $T \beta R I$ caps the $T \beta R$ Il phosphorylation sites, thus further stabilizing the inactive conformation of T $\beta R I$ [12].

\section{SMADs as mediators of TGF- $\beta$ signaling}

Proteins of the SMAD family are the first identified substrates of the TGF- $\beta$ type I receptor kinases. They play a central role in the transduction of receptor signals to specific target genes in the nucleus. So far, eight SMAD family members have been identified which, based on structural and functional differences, have been subdivided into three groups: (1) receptor-associated SMADs (R-SMADs) are direct substrates of TGF- $\beta$ family receptor kinases (SMAD1, $2,3,5,8),(2)$ co-SMADs that associate during signaling with these receptor-regulated SMADs (SMAD4), and (3) inhibitory SMADs $($ SMAD6, 7) that antagonize the signaling function of the former groups. Among the RSMADs, SMAD1, SMAD5 and SMAD8 are substrates for BMP type I receptors [13] and accordingly mediate BMP signals, while SMAD2 and SMAD3 are T $\beta$ RI substrates and mediate both TGF- $\beta$ and activin signals [14]. R-SMADs interact directly with ligandactivated $T \beta R I$ and are subsequently phosphorylated on two serine residues within a 
conserved -SSXS-motif at their C-terminus [2]. SARA (SMAD Anchor for Receptor Activation), a FYVE domain membrane-bound protein that interacts directly with SMAD2 and SMAD3, facilitates their recruitment to the activated receptor complexes by controlling the subcellular localization of the two R-SMADs [15]. R-SMAD recruitment and activation by $T \beta R I$ may also be regulated by the microtubule network [16]. Once phosphorylated, R-SMADs associate as heterodimeric complexes with SMAD4 and move into the nucleus where they bind DNA and initiate target gene transactivation, either alone or in association with other transcriptional partners (Fig. 1) [2].

Inhibitory SMADs have the ability to form stable associations with $T \beta R I$, and to interfere with the phoshorylation of R-SMADs and their heteromerization with SMAD4 [17; 18]. SMAD6 may also compete specifically with SMAD4 for binding to the BMP receptor-activated SMAD1, by forming an inactive SMAD1/SMAD6 complex in the cytoplasm [19]. Most recently, SMAD7 has been shown to interact with the E3 ubiquitin ligases Smurf 1 and Smurf 2, recruiting them to $T \beta R$ complexes and inducing the degradation of activated $T \beta R I[20 ; 21]$.

R-SMADs and co-SMADs are characterized by two highly conserved globular Nterminal and C-terminal domains, $\mathrm{MH} 1$ and $\mathrm{MH} 2$ (MAD Homology domain), respectively, and a linker region of variable length and sequence [22]. The MH2 domain from R-SMADs contains the -SSXS- receptor phosphorylation site. Once phosphorylated by activated receptor kinases, the $\mathrm{MH} 2$ domain dissociates from the $\mathrm{MH} 1$ domain through conformational changes, allowing the signaling cascade to proceed [23]. In the basal state the MH2 domain mediates the association of R-SMADs with type I receptors [24], while in the activated state the $\mathrm{MH} 2$ domain is involved in protein/protein interactions with co-SMADs, various DNA-binding cofactors, and transcriptional coactivators and corepressors. Once in the nucleus, activated R-SMADs 
contact DNA, which, in the case of SMAD3, is the DNA sequence CAGAC, through their MH1 domain [22; 25]. The presence of a 30 amino-acid insertion within the MH1 domain of SMAD2 as compared to that of SMAD3 prevents its direct interaction with specific DNA-binding motifs. Accordingly, SMAD2 dependent gene transcription requires the recruitment of putative transcription factors like FAST1 and FAST2, which allows the binding of the SMAD2/SMAD4/FAST-1 complexes to activin response elements $[26 ; 27 ; 28]$.

\section{Coactivators and corepressors of SMAD-dependent gene transcription}

In the nucleus, activated SMAD complexes may either activate or repress gene expression, depending on the recruitment of coactivators or corepressors into transcriptional complexes. The role for CREB Binding Protein (CBP) and p300 as essential coactivators for SMAD-driven gene expression has been well documented [29; 30; 31; 32; 33], and competition for p300/CBP has been suggested to mediate some examples of signal-induced transcriptional repression. Indeed, in the context of SMAD signaling, p300/CBP squelching by c-Jun or STAT1 may explain, at least in part, the antagonism exerted by tumor necrosis factor- $\alpha$ (TNF- $\alpha)$ and interferon- $\gamma$ (IFN- $\gamma$ ) against SMAD signaling [34; 35]. In addition, we have recently established that agents that activate PKA, e.g. $\mathrm{PGE}_{2}$ and $\mathrm{cAMP}$ increasing agents, are able to antagonize SMAD signaling via PKA-dependent, CREB-mediated, disruption of SMAD-p300/CBP complexes (Fig. 1) [36].

SMADs may also recruit transcriptional corepressors such as TG3-interacting factor (TGIF) [37], Sloan-Kettering Institute proto-oncogene (SKI), Ski-related novel gene $\mathrm{N}$ (SnoN) [38; 39], or SNIP1 [40]. Generally, these proteins bind chromatin-condensating histone deacetylases, which oppose the function of the histone acetyltransferase 
activity associated with the coactivators p300 and CBP. For example, overexpression of SNIP1 inhibits multiple gene responses to TGF- $\beta$ and p300/CBP, as well as the formation of SMAD4/p300 complexes [40]. Even a slight reduction in the activity of TGIF has been shown to have devastating developmental consequences [37]. Thus, the level of expression of these corepressors has important physiological consequences, by either setting a threshold for TGF- $\beta$-induced transcriptional activation involving p300/CBP or helping to terminate TGF- $\beta$ signal.

\section{Transcriptional regulation of SMAD target genes}

Once in the nucleus, activated SMAD complexes become transcriptional factors binding directly to SMAD-specific DNA-binding motifs. One of the first described genuine SMAD binding sequences, which binds an activated SMAD3 complex in response to a TGF- $\beta$ signal, was identified within the human COL7A1 promoter [41; 42]: TGF- $\beta$ upregulation of $C O L 7 A 1$ gene expression is mediated by rapid and transient binding of a SMAD-containing complex to a bipartite element consisting of two CAGA repeats in its 5' end, and a Medea-like (Drosophilia SMAD4 homologue) binding site in 3', framing an AP-1 binding site whose integrity is not necessary for either SMADdriven transactivation or SMAD/DNA complex formation [43]. Subsequently, CAGA elements have been characterized as optimal for recombinant SMAD3 and SMAD4 binding [25] and this sequence has been identified within the promoter regions of numerous TGF- $\beta$-regulated genes, including plasminogen activator inhibitor 1 (PAI-1) [44], JunB [45], COL1A2 [46], c-Jun [45], SMAD7 [47], platelet-derived growth factor B-

chain [48], integrin $\beta 5$ [49], cyclin-dependent kinase inhibitor $p 15^{\mathrm{INK} 4}$ [50], or connective tissue growth factor [51]. Moreover, several extracellular matrix (ECM) encoding genes are direct SMAD targets, including COL1A2, COL3A1, COL5A2, COL6A1, COL6A3, 
and TIMP-1, illustrating the key role of the SMAD signaling pathway for the simultaneous activation of fibrillar collagen genes by TGF- $\beta$ [52].

\section{The role of TGF- $\beta$ in tissue fibrosis and wound healing}

TGF- $\beta$ is a crucial regulator of ECM deposition, as it control both the expression of components of ECM network, such as the fibrillar collagens and fibronectin, and the expression of protease inhibitors, including PAI-1 or TIMPs [53]. These combined anabolic and anti-catabolic effects of TGF- $\beta$ make it a key growth factor in the development of tissue fibrosis [54]. Indeed, type I collagen and ECM deposition is one of the unifying histopathologic hallmarks of fibrotic disorders such as liver cirrhosis, renal sclerosis, systemic sclerosis and keloid scars. Mechanistically, collagen deposition in the skin could result from either enhanced biosynthetic activity or from a reduced rate of degradation, both phenomena leading to an imbalance in the collagen turnover in affected tissues.

Various studies have provided evidence that transcriptional activation of collagen gene expression is probably the most important regulatory mechanism leading to fibrosis [55; 56]. SMADs, the only downstream substrates of T $\beta$ RI known so far, are central in most actions of the TGF- $\beta$ family regarding ECM gene expression [52; 53 ; 57]. However, other factors such as connective tissue growth factor, may contribute to some of the TGF- $\beta$ effects on extracellular matrix gene expression (reviewed in [58]). In addition TGF- $\beta$ has been reported to activate members of the stressed activated MAP kinase cascade in various cell types $[59 ; 60 ; 61 ; 62]$. The relevance of these signaling pathways in the context of tissue fibrosis is still not fully understood, but in vitro studies suggest that TGF- $\beta$-activated p38 phosphorylation may be implicated in COL1A1 gene expression in dermal fibroblasts [63; 64]. In addition, in keloid fibroblasts the 
synchronous activation of the ERK and phosphatidylinositol 3-kinase pathway has been demonstrated to be critical for increased collagen type I and III production [65].

In contrast to predictions made on the basis of the ability of exogenous TGF- $\beta$ to improve wound healing, SMAD3-null mice paradoxically show accelerated cutaneous wound healing compared to wild-type mice, characterized by an increased rate of reepithelialization and significantly reduced local infiltration of monocytes [66]. From these data, it may therefore be concluded that SMAD3 may mediate in vivo signaling that is inhibitory to epithelial wound healing and that during the physiological process of wound healing, suppression of SMAD3 levels may engage. Thus, complete loss of this signaling intermediate in SMAD3-null mice results in further acceleration of the wound closure. Of note, reduced deposition of ECM in these mice could be abolished by exogenous TGF- $\beta 1$, implicating that ECM gene regulation by TGF- $\beta$ may also occur via SMAD3-independent mechanisms. Together, this report provides support for therapeutic intervention aimed at disrupting the SMAD3 pathway in vivo, in the context of impaired wound healing.

\section{Interfering with the fibrotic process at the transcriptional level: mechanisms of antagonism between pro-inflammatory cytokines and TGF- $\beta$}

It is reasonable to hypothesize that a better understanding of the mechanisms of TGF- $\beta$-mediated upregulation of ECM gene expression in fibrotic tissue will provide novel approaches to the therapy of these essentially incurable diseases. Accordingly, a better understanding of the mechanisms by which pro-inflammatory cytokines, such as TNF- $\alpha$, are able to interfere with the TGF- $\beta$-induced SMAD signaling are of utmost importance. TNF- $\alpha$ has been suggested to block SMAD signaling via mechanisms that implicate either c-Jun [34] or nuclear factor $\kappa B$ (NF-kB) [67]. The RelA subunit of NF-kB 
mediates TNF- $\alpha$-induced expression of the inhibitory SMAD, SMAD7 (Fig. 1 and 3), which, in turn, blocks TGF- $\beta$ signaling [67]. Data from our own laboratory indicate that C-Jun and JunB, both activated by TNF- $\alpha$ via the Jun-N-terminal kinase (JNK) pathway, are also capable of interrupting SMAD3-mediated transcription: Jun/SMAD3 complexes may form off-DNA, preventing SMAD3 binding to cognate DNA sequences [34]. JNK

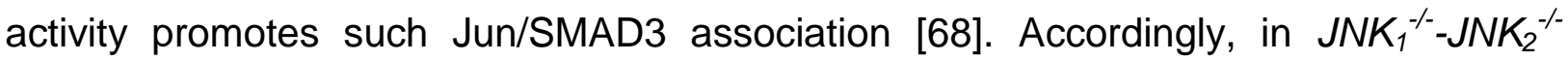
$\left(J N K^{--}\right)$fibroblasts, TNF- $\alpha$ inhibited basal COL1A2 expression but had no effect on TGF- $\beta$-driven gene transactivation unless jnk1 was introduced exogenously (Fig. 1 and 2) [69]. On the contrary lack of NF-kB activity in NF-kB Essential Modulator knockout $\left(N M^{-/}\right)$fibroblasts did not influence the antagonism exerted by TNF- $\alpha$ against TGF- $\beta$ but prevented repression of basal COL1A2 gene expression [69]. These results defined an alternate usage of distinct signaling pathways by TNF- $\alpha$ to inhibit the expression of COL1A2, depending on the activation state of this target gene. With regard to JNK function in the context of ECM turnover, these findings are complementary to a recent study indicating that a synthetic inhibitor of JNK, SP600125, suppresses interleukin-1induced phospho-Jun accumulation, Jun-DNA interactions and interstitial collagenase (MMP-1) gene expression in synovial fibroblasts [70]. Thus the benefit of JNK targeting in degenerative inflammatory diseases such as rheumatoid arthritis may result not only from blocking degradative events induced by interleukin-1 or TNF- $\alpha$, but also from preventing cytokines to antagonize the anabolic functions of TGF- $\beta$ on ECM deposition. Conversely, means to activate the JNK pathway may be of interest in pathological situations where interfering with TGF- $\beta$ signaling and subsequent ECM deposition is critical, such as in fibrosis.

The pleiotropic cytokine IFN- $\gamma$ exerts opposite effects on diverse cellular functions modulated by TGF- $\beta[71 ; 72 ; 73]$. It has been shown that in cells of epithelial origin, 
IFN- $\gamma$ induces the expression of SMAD7 via the activation of the JAK1 and STAT1, SMAD7 preventing the interaction of SMAD3 with the TGF- $\beta$ receptor [74]. Another mechanism by which the JAK/STAT pathway may alter SMAD-driven transcription, involves competition between activated STAT1 and SMAD3 for limiting amounts of cellular p300/CBP coactivators, a mechanism which may explain the antagonistic modulation of IFN- $\gamma$ against TGF- $\beta$-induced COL1A2 gene transcription (Fig. 3) [35]. Alternatively, IFN- $\gamma$ may inhibit COL1A2 gene transcription, both basal and induced by TGF- $\beta$ [72; 75]. IFN- $\gamma$ activates the transcription factor $\mathrm{YB}-1$, which not only binds a proximal region of the COL1A2 promoter [75], but also physically interacts with SMAD3 to prevent its binding to the TGF- $\beta$-response element of the COL1A2 promoter [76]. Because TGF- $\beta$ and IFN- $\gamma$ are secreted by inflammatory cells at sites of tissue injury, one may assume that their antagonistic interactions regulating collagen synthesis are likely to be important for the maintenance of connective tissue homeostasis.

\section{Experimental targeting of SMAD signaling in fibrosis}

SMAD7, a natural antagonist of TGF- $\beta$ signaling, acts both by preventing SMAD2/3receptor interactions and subsequent SMAD phosphorylation, and by recruiting E3 ubiquitin ligases called Smurf1 and Smurf2 to the receptor complexes, leading to the degradation of the latter. It has been suggested that defects in SMAD7 may, in certain instances, lead to fibrotic conditions, as reported in the heart and in scleroderma. However, ligand-independent constitutive activation of the intracellular TGF- $\beta$ /SMAD signaling axis in scleroderma fibroblasts, without profound differences of SMAD7 mRNA levels between control and scleroderma fibroblasts, has also been reported [77].

The therapeutic potential of targeted delivery of this inhibitory SMAD family member to prevent TGF- $\beta$-mediated fibrosis in vivo has been confirmed in various experimental 
models of kidney, lung and liver fibrosis. Thus, intratracheal injection of a recombinant adenovirus carrying mice SMAD7 CDNA prevents bleomycin-induced lung fibrosis in mice [78]. Similar promising results with SMAD7 gene transfer have been achieved in in vivo models of liver or renal fibrosis [79; 80]. In systemic sclerosis, deficient SMAD7 expression is regarded as a putative molecular defect leading to disease development [81]. Thus, it is not surprising that in vitro adenoviral gene transfer with SMAD7 reestablishes normal, not pathologically intensified, TGF- $\beta$ signaling in systemic sclerosis fibroblasts [81]. Several hurdles remain before TGF- $\beta$ targeting can be considered a realistic therapeutic alternative for the treatment of fibrosis, as significant problems may arise with regard to overall tolerance or biological outcome. Even though transgenic mice expressing a soluble form of $T \beta R I I$ have been shown to be protected against metastasis without adverse side effects [82], it has also been shown that fibroblastspecific expression of a kinase-deficient $T \beta R I$ in mice leads to paradoxical activation of TGF- $\beta$ signaling pathways with dermal and pulmonary fibrosis [83]. Furthermore, epithelial overexpression of SMAD7, or that of a dominant-negative TGF- $\beta$ type II receptor, results in severe pathological alterations of epithelial tissues in transgenic mice $[84 ; 85]$, which could suggest that mesenchyme-specific targeting of the SMAD pathway may be required.

\section{Conclusions}

There have been major advances in our understanding of the TGF- $\beta$-induced intracellular signaling since the identification of SMAD proteins as direct links between the cell surface and the nucleus. The recent development of several SMAD pathway specific knockout mice and transgenic animals has confirmed the pivotal nature of the SMAD pathway in fibrogenesis and tumorigenesis. Still, several difficulties remain 
before the TGF- $\beta$ /SMAD pathway can be efficiently targeted in situations such as tissue fibrosis or impaired wound healing. In particular, the precise spatio-temporal role of each TGF- $\beta /$ SMAD pathway component during the development of excessive ECM deposition leading to tissue fibrosis remains to be ascertained.

\section{Acknowledgments}

Supported by INSERM, Association pour la Recherche contre le Cancer (ARC, France), Ligue Nationale Contre le Cancer, section de Paris, Electricité de France (Service de radioprotection). D.J. and M.S. are recipients of post-doctoral fellowships

from ARC (France) and Deutsche Forschungsgemeinschaft (DFG, Germany), respectively. 


\section{References}

[1] Massague J. TGF- $\beta$ signal transduction. Annu Rev Biochem 67:753-91, 1998

[2] Massague J, Wotton D. Transcriptional control by the TGF- $\beta / S M A D$ signaling system. EMBO J 19:1745-54, 2000

[3] Sporn MB, Roberts AB. The transforming growth factor-betas: past, present, and future. Ann N Y Acad Sci 593:1-6, 1990

[4] Shull MM, Ormsby I, Kier AB, Pawlowski S, Diebold RJ, Yin M, Allen R, Sidman C, Proetzel G, Calvin $\mathrm{D}$, . Targeted disruption of the mouse transforming growth factor- $\beta 1$ gene results in multifocal inflammatory disease. Nature 359:693-99, 1992

[5] Sanford LP, Ormsby I, Gittenberger-de Groot AC, Sariola H, Friedman R, Boivin GP, Cardell EL, Doetschman T. TGF $\beta 2$ knockout mice have multiple developmental defects that are nonoverlapping with other TGF $\beta$ knockout phenotypes. Development 124:2659-70, 1997

[6] Proetzel G, Pawlowski SA, Wiles MV, Yin M, Boivin GP, Howles PN, Ding J, Ferguson MW, Doetschman $T$. Transforming growth factor- $\beta 3$ is required for secondary palate fusion. Nat Genet 11:409-14, 1995

[7] Shah M, Foreman DM, Ferguson MW. Neutralisation of TGF- $\beta 1$ and TGF- $\beta 2$ or exogenous addition of TGF- $\beta 3$ to cutaneous rat wounds reduces scarring. J Cell Sci 108:985-1002, 1995

[8] O'Kane S, Ferguson MW. Transforming growth factor $\beta$ s and wound healing. Int J Biochem Cell Biol 29:63-78, 1997

[9] Piek E, Heldin $\mathrm{CH}$, ten Dijke P. Specificity, diversity, and regulation in TGF- $\beta$ superfamily signaling. FASEB J 13:2105-24, 1999

[10] Lin HY, Wang XF, Ng-Eaton E, Weinberg RA, Lodish HF. Expression cloning of the TGF- $\beta$ type II receptor, a functional transmembrane serine/threonine kinase. Cell 68:775-85, 1992

[11] Huse M, Chen YG, Massague J, Kuriyan J. Crystal structure of the cytoplasmic domain of the type I TGF $\beta$ receptor in complex with FKBP12. Cell 96:425-36, 1999

[12] Persson U, Izumi H, Souchelnytskyi S, Itoh S, Grimsby S, Engstrom U, Heldin CH, Funa K, ten Dijke P. The L45 loop in type I receptors for TGF- $\beta$ family members is a critical determinant in specifying SMAD isoform activation. FEBS Lett 434:83-87, 1998

[13] Kretzschmar M, Liu F, Hata A, Doody J, Massague J. The TGF- $\beta$ family mediator SMAD1 is phosphorylated directly and activated functionally by the BMP receptor kinase. Genes Dev 11:98495, 1997

[14] Attisano L, Wrana JL. Mads and SMADs in TGF $\beta$ signalling. Curr Opin Cell Biol 10:188-94, 1998

[15] Tsukazaki T, Chiang TA, Davison AF, Attisano L, Wrana JL. SARA, a FYVE domain protein that recruits SMAD2 to the TGF $\beta$ receptor. Cell 95:779-91, 1998

[16] Dong C, Li Z, Alvarez R, Jr., Feng XH, Goldschmidt-Clermont PJ. Microtubule binding to SMADs may regulate TGF $\beta$ activity. Mol Cell 5:27-34, 2000

[17] Imamura T, Takase M, Nishihara A, Oeda E, Hanai J, Kawabata M, Miyazono K. SMAD6 inhibits signalling by the TGF- $\beta$ superfamily. Nature 389:622-26, 1997

[18] Nakao A, Afrakhte M, Moren A, Nakayama T, Christian JL, Heuchel R, Itoh S, Kawabata M, Heldin $\mathrm{NE}$, Heldin $\mathrm{CH}$, ten Dijke P. Identification of SMAD7, a TGF $\beta$-inducible antagonist of TGF- $\beta$ signalling. Nature 389:631-35, 1997

[19] Hata A, Lagna G, Massague J, Hemmati-Brivanlou A. SMAD6 inhibits BMP/SMAD1 signaling by specifically competing with the SMAD4 tumor suppressor. Genes Dev 12:186-97, 1998

[20] Kavsak P, Rasmussen RK, Causing CG, Bonni S, Zhu H, Thomsen GH, Wrana JL. SMAD7 binds to Smurf2 to form an E3 ubiquitin ligase that targets the TGF $\beta$ receptor for degradation. Mol Cell $6: 1365-75,2000$ 
[21] Ebisawa T, Fukuchi M, Murakami G, Chiba T, Tanaka K, Imamura T, Miyazono K. Smurf1 interacts with transforming growth factor- $\beta$ type I receptor through SMAD7 and induces receptor degradation. J Biol Chem 276:12477-80, 2001

[22] Shi Y, Wang YF, Jayaraman L, Yang $H$, Massague J, Pavletich NP. Crystal structure of a SMAD MH1 domain bound to DNA: insights on DNA binding in TGF- $\beta$ signaling. Cell 94:585-94, 1998

[23] Hata A, Lo RS, Wotton D, Lagna G, Massague J. Mutations increasing autoinhibition inactivate tumour suppressors SMAD2 and SMAD4. Nature 388:82-87, 1997

[24] Macias-Silva M, Abdollah S, Hoodless PA, Pirone R, Attisano L, Wrana JL. MADR2 is a substrate of the TGF $\beta$ receptor and its phosphorylation is required for nuclear accumulation and signaling. Cell 87:1215-24, 1996

[25] Zawel L, Dai JL, Buckhaults P, Zhou S, Kinzler KW, Vogelstein B, Kern SE. Human SMAD3 and SMAD4 are sequence-specific transcription activators. Mol Cell 1:611-17, 1998

[26] Labbe E, Silvestri C, Hoodless PA, Wrana JL, Attisano L. SMAD2 and SMAD3 positively and negatively regulate TGF $\beta$-dependent transcription through the forkhead DNA-binding protein FAST2. Mol Cell 2:109-20, 1998

[27] Liu B, Dou CL, Prabhu L, Lai E. FAST-2 is a mammalian winged-helix protein which mediates transforming growth factor- $\beta$ signals. Mol Cell Biol 19:424-30, 1999

[28] Chen X, Weisberg E, Fridmacher V, Watanabe M, Naco G, Whitman M. SMAD4 and FAST-1 in the assembly of activin-responsive factor. Nature 389:85-89, 1997

[29] Janknecht R, Wells NJ, Hunter T. TGF- $\beta$-stimulated cooperation of SMAD proteins with the coactivators CBP/p300. Genes Dev 12:2114-19, 1998

[30] Pouponnot C, Jayaraman L, Massague J. Physical and functional interaction of SMADs and p300/CBP. J Biol Chem 273:22865-68, 1998

[31] Feng XH, Zhang Y, Wu RY, Derynck R. The tumor suppressor SMAD4/DPC4 and transcriptional adaptor CBP/p300 are coactivators for SMAD3 in TGF- $\beta$-induced transcriptional activation. Genes Dev 12:2153-63, 1998

[32] Topper JN, DiChiara MR, Brown JD, Williams AJ, Falb D, Collins T, Gimbrone MA, Jr. CREB binding protein is a required coactivator for SMAD-dependent, transforming growth factor $\beta$ transcriptional responses in endothelial cells. Proc Natl Acad Sci U S A 95:9506-11, 1998

[33] Shen X, Hu PP, Liberati NT, Datto MB, Frederick JP, Wang XF. TGF- $\beta$-induced phosphorylation of SMAD3 regulates its interaction with coactivator p300/CREB-binding protein. Mol Biol Cell 9:330919,1998

[34] Verrecchia F, Pessah M, Atfi A, Mauviel A. Tumor necrosis factor- $\alpha$ inhibits transforming growth factor- $\beta$ /SMAD signaling in human dermal fibroblasts via AP-1 activation. J Biol Chem 275:3022631,2000

[35] Ghosh AK, Yuan W, Mori Y, Chen S, Varga J. Antagonistic regulation of type I collagen gene expression by interferon- $\gamma$ and transforming growth factor- $\beta$. Integration at the level of p300/CBP transcriptional coactivators. J Biol Chem 276:11041-48, 2001

[36] Schiller M, Verrecchia F, Mauviel A. Cyclic adenosine 3',5'-monophosphate-elevating agents inhibit transforming growth factor- $\beta$-induced SMAD3/4-dependent transcription via a protein kinase Adependent mechanism. Oncogene 22:8881-90, 2003

[37] Wotton D, Lo RS, Lee S, Massague J. A SMAD transcriptional corepressor. Cell 97:29-39, 1999

[38] Luo K, Stroschein SL, Wang W, Chen D, Martens E, Zhou S, Zhou Q. The Ski oncoprotein interacts with the SMAD proteins to repress TGF $\beta$ signaling. Genes Dev 13:2196-206, 1999

[39] Sun Y, Liu X, Ng-Eaton E, Lodish HF, Weinberg RA. SnoN and Ski protooncoproteins are rapidly degraded in response to transforming growth factor $\beta$ signaling. Proc Natl Acad Sci U S A 96:12442-47, 1999 
[40] Kim RH, Wang D, Tsang M, Martin J, Huff C, de Caestecker MP, Parks WT, Meng X, Lechleider RJ, Wang T, Roberts AB. A novel SMAD nuclear interacting protein, SNIP1, suppresses p300dependent TGF- $\beta$ signal transduction. Genes Dev 14:1605-16, 2000

[41] Vindevoghel L, Lechleider RJ, Kon A, de Caestecker MP, Uitto J, Roberts AB, Mauviel A. SMAD3/4-dependent transcriptional activation of the human type VII collagen gene (COL7A1) promoter by transforming growth factor $\beta$. Proc Natl Acad Sci U S A 95:14769-74, 1998

[42] Vindevoghel L, Kon A, Lechleider RJ, Uitto J, Roberts AB, Mauviel A. SMAD-dependent transcriptional activation of human type VII collagen gene (COL7A1) promoter by transforming growth factor- $\beta$. J Biol Chem 273:13053-57, 1998

[43] Verrecchia F, Vindevoghel L, Lechleider RJ, Uitto J, Roberts AB, Mauviel A. SMAD3/AP-1 interactions control transcriptional responses to TGF- $\beta$ in a promoter-specific manner. Oncogene 20:3332-40, 2001

[44] Dennler S, Itoh S, Vivien D, ten Dijke P, Huet S, Gauthier JM. Direct binding of SMAD3 and SMAD4 to critical TGF $\beta$-inducible elements in the promoter of human plasminogen activator inhibitor-type 1 gene. EMBO J 17:3091-100, 1998

[45] Jonk LJ, Itoh S, Heldin CH, ten Dijke P, Kruijer W. Identification and functional characterization of a SMAD binding element (SBE) in the JunB promoter that acts as a transforming growth factor- $\beta$, activin, and bone morphogenetic protein-inducible enhancer. J Biol Chem 273:21145-52, 1998

[46] Chen SJ, Yuan W, Mori Y, Levenson A, Trojanowska M, Varga J. Stimulation of type I collagen transcription in human skin fibroblasts by TGF- $\beta$ : involvement of SMAD 3. J Invest Dermatol 112:49-57, 1999

[47] Nagarajan RP, Zhang J, Li W, Chen Y. Regulation of SMAD7 promoter by direct association with SMAD3 and SMAD4. J Biol Chem 274:33412-18, 1999

[48] Taylor LM, Khachigian LM. Induction of platelet-derived growth factor B-chain expression by transforming growth factor- $\beta$ involves transactivation by SMADs. J Biol Chem 275:16709-16, 2000

[49] Lai CF, Feng X, Nishimura R, Teitelbaum SL, Avioli LV, Ross FP, Cheng SL. Transforming growth factor- $\beta$ up-regulates the $\beta 5$ integrin subunit expression via Sp1 and SMAD signaling. J Biol Chem 275:36400-36406, 2000

[50] Feng XH, Lin X, Derynck R. SMAD2, SMAD3 and SMAD4 cooperate with Sp1 to induce p15(INK4B) transcription in response to TGF- $\beta$. EMBO J 19:5178-93, 2000

[51] Holmes A, Abraham DJ, Sa S, Shiwen X, Black CM, Leask A. CTGF and SMADs, maintenance of scleroderma phenotype is independent of SMAD signaling. J Biol Chem 276:10594-601, 2001

[52] Verrecchia F, Chu ML, Mauviel A. Identification of novel TGF- $\beta$ /SMAD gene targets in dermal fibroblasts using a combined cDNA microarray/promoter transactivation approach. J Biol Chem 276:17058-62, 2001

[53] Verrecchia F, Mauviel A. Transforming growth factor- $\beta$ signaling through the SMAD pathway: role in extracellular matrix gene expression and regulation. J Invest Dermatol 118:211-15, 2002

[54] Verrecchia F, Mauviel A. Control of connective tissue gene expression by TGF $\beta$ : role of SMAD proteins in fibrosis. Curr Rheumatol Rep 4:143-49, 2002

[55] Uitto J, Kouba D. Cytokine modulation of extracellular matrix gene expression: relevance to fibrotic skin diseases. J Dermatol Sci 24 Suppl 1:S60-S69, 2000

[56] Jimenez SA, Saitta B. Alterations in the regulation of expression of the $\alpha 1$ (I) collagen gene (COL1A1) in systemic sclerosis (scleroderma). Springer Semin Immunopathol 21:397-414, 1999

[57] Takagawa S, Lakos G, Mori Y, Yamamoto T, Nishioka K, Varga J. Sustained activation of fibroblast transforming growth factor- $\beta / S M A D$ signaling in a murine model of scleroderma. J Invest Dermatol 121:41-50, 2003

[58] Leask A, Holmes A, Abraham DJ. Connective tissue growth factor: a new and important player in the pathogenesis of fibrosis. Curr Rheumatol Rep 4:136-42, 2002 
[59] Sano Y, Harada J, Tashiro S, Gotoh-Mandeville R, Maekawa T, Ishii S. ATF-2 is a common nuclear target of SMAD and TAK1 pathways in transforming growth factor- $\beta$ signaling. J Biol Chem 274:8949-57, 1999

[60] Atfi A, Djelloul S, Chastre E, Davis R, Gespach C. Evidence for a role of Rho-like GTPases and stress-activated protein kinase/c-Jun N-terminal kinase (SAPK/JNK) in transforming growth factor $\beta$-mediated signaling. J Biol Chem 272:1429-32, 1997

[61] Hocevar BA, Brown TL, Howe PH. TGF-beta induces fibronectin synthesis through a c-Jun Nterminal kinase-dependent, SMAD4-independent pathway. EMBO J 18:1345-56, 1999

[62] Hanafusa H, Ninomiya-Tsuji J, Masuyama N, Nishita M, Fujisawa J, Shibuya H, Matsumoto K, Nishida E. Involvement of the p38 mitogen-activated protein kinase pathway in transforming growth factor- $\beta$-induced gene expression. J Biol Chem 274:27161-67, 1999

[63] Varela-Rey M, Montiel-Duarte C, Oses-Prieto JA, Lopez-Zabalza MJ, Jaffrezou JP, Rojkind M, Iraburu MJ. p38 MAPK mediates the regulation of $\alpha 1$ (I) procollagen mRNA levels by TNF- $\alpha$ and TGF- $\beta$ in a cell line of rat hepatic stellate cells(1). FEBS Lett 528:133-38, 2002

[64] Sato M, Shegogue D, Gore EA, Smith EA, McDermott PJ, Trojanowska M. Role of p38 MAPK in transforming growth factor $\beta$ stimulation of collagen production by scleroderma and healthy dermal fibroblasts. J Invest Dermatol 118:704-11, 2002

[65] Lim IJ, Phan TT, Tan EK, Nguyen TT, Tran E, Longaker MT, Song C, Lee ST, Huynh HT. Synchronous activation of ERK and phosphatidylinositol 3-kinase pathways is required for collagen and extracellular matrix production in keloids. J Biol Chem 278:40851-58, 2003

[66] Ashcroft GS, Yang X, Glick AB, Weinstein M, Letterio JL, Mizel DE, Anzano M, Greenwell-Wild T, Wahl SM, Deng C, Roberts AB. Mice lacking SMAD3 show accelerated wound healing and an impaired local inflammatory response. Nat Cell Biol 1:260-266, 1999

[67] Bitzer M, von Gersdorff G, Liang D, Dominguez-Rosales A, Beg AA, Rojkind M, Bottinger EP. A mechanism of suppression of TGF- $\beta / S M A D$ signaling by NF-kB/RelA. Genes Dev 14:187-97, 2000

[68] Verrecchia F, Tacheau C, Wagner EF, Mauviel A. A central role for the JNK pathway in mediating the antagonistic activity of pro-inflammatory cytokines against transforming growth factor- $\beta$-driven SMAD3/4-specific gene expression. J Biol Chem 278:1585-93, 2003

[69] Verrecchia F, Wagner EF, Mauviel A. Distinct involvement of the Jun-N-terminal kinase and NF- $\kappa B$ pathways in the repression of the human COL1A2 gene by TNF- $\alpha$. EMBO Rep 3:1069-74, 2002

[70] Han Z, Boyle DL, Chang L, Bennett B, Karin M, Yang L, Manning AM, Firestein GS. c-Jun Nterminal kinase is required for metalloproteinase expression and joint destruction in inflammatory arthritis. J Clin Invest 108:73-81, 2001

[71] Bauvois B, Rouillard D, Sanceau J, Wietzerbin J. IFN- $\gamma$ and transforming growth factor- $\beta 1$ differently regulate fibronectin and laminin receptors of human differentiating monocytic cells. $J$ Immunol 148:3912-19, 1992

[72] Higashi K, Kouba DJ, Song YJ, Uitto J, Mauviel A. A proximal element within the human $\alpha 2$ (I) collagen (COL1A2) promoter, distinct from the tumor necrosis factor- $\alpha$ response element, mediates transcriptional repression by interferon- $\gamma$. Matrix Biol 16:447-56, 1998

[73] Xiao BG, Zhang GX, Ma CG, Link H. Transforming growth factor- $\beta 1$ (TGF- $\beta 1$ )-mediated inhibition of glial cell proliferation and down-regulation of intercellular adhesion molecule-1 (ICAM-1) are interrupted by interferon- $\gamma$ (IFN- $\gamma$ ). Clin Exp Immunol 103:475-81, 1996

[74] Ulloa L, Doody J, Massague J. Inhibition of transforming growth factor- $\beta$ /SMAD signalling by the interferon- $\gamma /$ STAT pathway. Nature 397:710-713, 1999

[75] Higashi K, Inagaki Y, Fujimori K, Nakao A, Kaneko H, Nakatsuka I. Interferon- $\gamma$ Interferes with Transforming Growth Factor- $\beta$ Signaling through Direct Interaction of YB-1 with SMAD3. J Biol Chem 278:43470-43479, 2003

[76] Higashi K, Inagaki Y, Suzuki N, Mitsui S, Mauviel A, Kaneko H, Nakatsuka I. Y-box-binding protein YB-1 mediates transcriptional repression of human $\alpha 2(\mathrm{I})$ collagen gene expression by interferon- $\gamma$. J Biol Chem 278:5156-62, 2003 
[77] Mori Y, Chen SJ, Varga J. Expression and regulation of intracellular SMAD signaling in scleroderma skin fibroblasts. Arthritis Rheum 48:1964-78, 2003

[78] Nakao A, Fujii M, Matsumura R, Kumano K, Saito Y, Miyazono K, Iwamoto I. Transient gene transfer and expression of SMAD7 prevents bleomycin-induced lung fibrosis in mice. J Clin Invest 104:5-11, 1999

[79] Dooley S, Hamzavi J, Breitkopf K, Wiercinska E, Said HM, Lorenzen J, ten Dijke P, Gressner AM. SMAD7 prevents activation of hepatic stellate cells and liver fibrosis in rats. Gastroenterology 125:178-91, 2003

[80] Lan HY, Mu W, Tomita N, Huang XR, Li JH, Zhu HJ, Morishita R, Johnson RJ. Inhibition of renal fibrosis by gene transfer of inducible SMAD7 using ultrasound-microbubble system in rat UUO model. J Am Soc Nephrol 14:1535-48, 2003

[81] Dong C, Zhu S, Wang T, Yoon W, Li Z, Alvarez R, Jr., ten Dijke P, White B, Wigley FM, Goldschmidt-Clermont PJ. Deficient SMAD7 expression: a putative molecular defect in scleroderma. Proc Natl Acad Sci U S A 99:3908-13, 2002

[82] Yang YA, Dukhanina O, Tang B, Mamura M, Letterio JJ, MacGregor J, Patel SC, Khozin S, Liu ZY, Green J, Anver MR, Merlino G, Wakefield LM. Lifetime exposure to a soluble TGF- $\beta$ antagonist protects mice against metastasis without adverse side effects. J Clin Invest 109:1607-15, 2002

[83] Denton CP, Zheng B, Evans LA, Shi-wen X, Ong VH, Fisher I, Lazaridis K, Abraham DJ, Black $\mathrm{CM}$, de Crombrugghe B. Fibroblast-specific expression of a kinase-deficient type II transforming growth factor $\beta$ (TGF $\beta$ ) receptor leads to paradoxical activation of TGF $\beta$ signaling pathways with fibrosis in transgenic mice. J Biol Chem 278:25109-19, 2003

[84] He W, Li AG, Wang D, Han S, Zheng B, Goumans MJ, ten Dijke P, Wang XJ. Overexpression of SMAD7 results in severe pathological alterations in multiple epithelial tissues. EMBO J 21:25802590, 2002

[85] Wang XJ, Greenhalgh DA, Bickenbach JR, Jiang A, Bundman DS, Krieg T, Derynck R, Roop DR. Expression of a dominant-negative type II transforming growth factor $\beta$ (TGF- $\beta$ ) receptor in the epidermis of transgenic mice blocks TGF- $\beta$-mediated growth inhibition. Proc Natl Acad Sci U S A 94:2386-91, 1997 


\section{Figure legends}

Fig. 1. The TGF- $\beta$ /SMAD signaling pathway. This schematic diagram summarizes the various aspects of SMAD signaling, from receptor activation to gene transcription. Interference mechanisms, e.g. SMAD7 or cytokine-induced pathways, are depicted. For further detail, refer to the corresponding text within the manuscript.

Fig. 2. The stress-activated MAP Kinase cascade downstream the TNF- $\alpha$ receptors. Binding of TNF- $\alpha$ to its receptors induces the activation of MAP kinase kinase kinases (MAPKKK) MEKK1 and/or ASK1 via the adaptor protein TRAF2 (TNF-R associated factor 2). These activated MAPKKKs then activate the MAPKK MKK4 and MKK7 which, in turn, phosphorylate the two tyrosine/threonine residues of JNK. MKK4 may also phosphorylate the p38 MAP kinase, which itself is predominantly activated by MKK3 and MKK6 (downstream of ASK1 and TAK1). Activated JNK binds to the Nterminal region of c-Jun and phosphorylates it at Ser63 and Ser73. ATF-2 may be phosphorylated and activated by both JNK and p38, whereas c-Jun is phosphorylated only by JNK.

Fig. 3. The NF-kB pathway. NF-kB transcription factors are normally found in the cytoplasm, retained by interaction with the inhibitory molecule $\mathrm{I}_{\kappa} \mathrm{B}$ (Inhibitor of $\kappa \mathrm{B}$ ). Receptor-mediated activation of the NF-kB signaling cascade results in the phosphorylation, ubiquitination and degradation of $I_{\kappa} B$ by $26 S$ proteasome, allowing nuclear translocation of the transcriptional active NF-kB complex. Responsible for phosphorylation of $I_{\kappa} B$, it is a high molecular weight complex containing two kinases (IKK $\alpha$ and IKK $\beta$ ) and a regulatory subunit (NEMO). 